\title{
THE ASSOCIATION BETWEEN FAMILY SUPPORT, SOCIAL SUPPORT, GROSS MOTORIC SKILL, AND QUALITY OF LIFE AMONG CHILDREN WITH CEREBRAL PALSY
}

\author{
Alinda Nur Ramadhani'), Rita Benya Adriani²), Harsono Salimo3) \\ ${ }^{1)}$ Masters Program on Public Health, Universitas Sebelas Maret \\ ${ }^{2)}$ Department of Speech Therapy, Health Polytechnics, \\ Ministry of Health Surakarta \\ 3)Department of Pediatric, Dr. Moewardi Hospital, Surakarta
}

\begin{abstract}
Background: With a prevalence of approximately 2 per 1,00o births, cerebral palsy (CP) is the most common physical disability in childhood and is considered to be a permanent disorder of movement and posture. Assessment of Quality of Life (QOL) is increasingly used as a mechanism to gain insight into a child's life, to identify areas of life that are positive or challenging and to inform and evaluate interventions. This study aimed to determine the association between family support, social support, and gross motoric skill, and quality of life, among children with cerebral palsy.

Subject and Method: This was a cross sectional study conducted at Fondation for the Care of Disable Children (YPAC) and Pediatric Neurodevelopmental Therapy Center, Surakarta, Central Java, from April to May 2018. A sample of 110 children with cerebral palsy was selected for this study with fixed disease sampling. The dependent variable was quality of life. The independent variables were family support, social support, and gross motoric skill. The data quality of life collected by Cerebral Palsy Quality of Life (CP-QOL) questionnaire and analyzed by a multiple logistic regression model.

Results: Quality of life was increased by strong family support $(\mathrm{OR}=1.22$; 95\% $\mathrm{CI}=0.22$ to $2.22 ; \mathrm{p}=0.016)$ and gross motoric skill $(\mathrm{OR}=2.79 ; 95 \% \mathrm{CI}=1.44$ to $4.15 ; \mathrm{p}=0.001)$. Quality of life was decreased by low social support $(\mathrm{OR}=0.91$; $95 \% \mathrm{CI}=-0.76$ to $1.91 ; \mathrm{p}=0.070$ ).
\end{abstract}

Conclusion: Quality of life is increased by family support and gross motoric skill, but is decreased by low social support

Keywords: family support, social support, gross motoric skill, quality of life

\section{Correspondence:}

Alinda Nur Ramadhani. Masters Program on Public Health, Universitas Sebelas Maret, Jl. Ir. Sutami 36A, Surakarta 57126, Central Java.

Email: aramadhani95@gmail.com. Mobile: 085742133035. 